\title{
A METHODOLOGICAL FRAMEWORK FOR THE INTERDISCIPLINARY LITERARY TEXT ANALYSIS
}

\author{
Bohdana Labinska \\ http://orcid.org/0000-0001-5232-8022 \\ b.labinska@chnu.edu.ua \\ Yuriy Fedkovych Chernivtsi National University, Ukraine
}

Iryna Osovska

http://orcid.org/0000-0002-8109-658X

i.osovska@chnu.edu.ua

Yuriy Fedkovych Chernivtsi National University, Ukraine

Oxana Matiychuk

http://orcid.org/0000-0001-6204-2888

o.matiychuk@chnu.edu.ua

Yuriy Fedkovych Chernivtsi National University, Ukraine

Nataliia Vyspinska

http://orcid.org/0000-0002-5705-4291

n.vyspinska@chnu.edu.ua

Yuriy Fedkovych Chernivtsi National University, Ukraine

Received August 5, 2020; Revised September 4, 2020; Accepted September 27, 2020

\begin{abstract}
All scientific endeavours require researchers to develop an understanding of the available methodological tools to perform the needed studies. These tools can be applied depending on the field, purpose and context of the study. This article outlines and argues for ways to construct methodological framework appropriate for an in-depth interdisciplinary analysis of a literary text. The purpose of this study is to build the interdisciplinary methodological framework for literary text analysis using approaches of two humanities sciences - pedagogy and philology (linguistics and literature). The material for the research is a contemporary fairy tale Bunny NonHopper and His Brave Mommy by Oksana Drachkovska, the Ukrainian writer and journalist. Relevance, innovation, importance and complexity of the author's fairy tale theme, which appears both in the field of modern pedagogy and current philological interpretations justified our choice. Among the methods applied in the paper are literary studies interpretation that outlines a place of the fairy tale in the context of similar Ukrainian and foreign literature and reveals features of the its gender constructions; linguistic analysis based on communicative-pragmatic and conceptual approaches that focus on the text-discursive level along with pedagogical approaches that enable the representation of the text's educational potential. The suggested framework consists of two levels - general scientific and specific scientific. On the general
\end{abstract}

(C) Labinska, Bohdana; Osovska, Iryna; Matiychuk, Oxana; Vyspinska, Nataliia, 2020.

This is an Open Access article distributed under the terms and conditions of the Creative Commons Attribution 4.0 International Licence (http://creativecommons.org/licenses/by/4.0).

East European Journal of Psycholinguistics, 7(2), 155-178. https://doi.org/10.29038/eejpl.2020.7.2.1ab 
scientific level, it deploys systematic, synergetic, and paradigmatic approaches, whereas on the specific scientific level - linguistic approaches (communicative pragmatic and conceptual), literary studies approaches (intertextual and gender), and pedagogical approaches (integrated, inclusive, humanistic, empowerment), thus employing knowledge and specifics of each science. Besides a system-building function aimed to obtain comprehensive information about the object of the study, the proposed methodological framework for the interdisciplinary literary text analysis embraces an anthropocentric paradigm centred on children with special educational needs.

Keywords: methodological tools, literary studies, linguistics, pedagogy, interdisciplinary literary text analysis, special educational needs, modern Ukrainian fairy tale, inclusion literature.

Лабінська Богдана, Осовська Ірина, Матійчук Оксана, Виспінська Наталія. Методологічний інструментарій міждисциплінарних досліджень тексту.

Анотація. Умовою розвитку будь-якої науки і досягнення значущих результатів $\epsilon$ іiі методологічна озброєність. Методологічне обгрунтування визначає загальний підхід до дослідження й розкриває водночас більш конкретні положення, які виступають методологічними орієнтирами, що розвивають лінійну або кумулятивну систему наукового знання. Необхідність міждисциплінарної методології досліджень конкретних об'єктів викликана глобалізованою та міжкультурною взаємодією в гуманітарних науках, зокрема об'єднання кількох спеціальностей (наприклад, мовознавства 3 літературознавством; соціальної, вікової педагогіки з лінгводидактикою) в окремі наукові сфери. Виходячи 3 цього, методологічний інструментарій розширюється, взаємодоповнюється, інтегрується за рахунок залучення підходів, методів, принципів різних наук, що уможливлює глибший та усесторонній аналіз об'єктів досліджень. Мета цього дослідження полягає у створенні міждисциплінарної методики аналізу тексту 3 використанням інструментарію двох гуманітарних дисциплін - педагогіки та філології (мовознавства й літературознавства). Матеріалом для дослідження обрано сучасну казку української письменниці та журналістки Оксани Драчковської «Зайчик-нестрибайчик та його смілива мама». Наш вибір був зумовлений актуальністю, інноваційністю, важливістю та комплексністю теми авторської казки, яка фігурує як у площині сучасної педагогіки, так i актуальних філологічних проекціях. Послідовність роботи визначають літературознавча інтерпретація, яка окреслить місце твору в контексті подібної української та зарубіжної літератури й виявить деякі особливості гендерних конструкцій казки; лінгвістичний аналіз із застосуванням комунікативно-прагматичного та концептуального підходів, що детально зосереджуються на текстово-дискурсивному рівні; педагогічні підходи, що уможливлять репрезентацію виховного потенціалу досліджуваного тексту-дискурсу. Слід зазначити, що загальнонауковий рівень цього інтегрованого міждисциплінарного дослідження складають системний, синергетичний та парадигмальний підходи. Запропонований міждисциплінарний інструментарій вибудуваний на антропоцентричній парадигмі, в центрі якої є людина - дитина 3 особливими освітніми потребами. Літературознавчі, мовознавчі, та педагогічні методологічні орієнтири виступають інтелектуальною схемою послідовності та зв'язку підходів, методів, принципів. Інтегруючи знання різних наук 3 урахуванням специфіки кожної, міждисциплінарний інструментарій виконує системотвірну функцію 3 метою отримання різнобічних відомостей щодо об'єкта дослідження.

Ключові слова: методологічний інструментарій, літературознавство, мовознавство, педагогіка, міждисииплінарне дослідження тексту, особливі освітні потреби, сучасна украӥнська казка, інклюзивна література. 
Fact Furnnean Inurnal of Pevcholinguictice Volume 7 Numher 7 on Methodological Framework for the Interdisciplinary Literary Text Analysis

\section{Introduction}

A precondition for the development of any science and achievement of significant results is the methodological framework. Without methodological knowledge, which includes: methodological reflection (ability to analyse personal scientific activity), capacity for scientific substantiation, critical understanding and creative employment of certain concepts, forms and methods of cognition, management and design, it is impossible to competently conduct scientific research. (Kraevskij, 2009). Ziaziun emphasizes that the set of ideas, theories and approaches that are chosen as a methodological basis of a scientific investigation, constitutes a "prism" which enables clarification of the essence of the research object, shaping notion about it, selection of means and conditions of improvement as well as effective development (Ziaziun, 2011, p. 7). It allows scholars to balance the system of scientific research results, which is why the methodological basis of any research is understanding that science is a developing system as well as a special type of systematic organization of scientific works.

The modern methodology includes a system of knowledge of the objective laws of the development of the studied object, as well as the outlook system on future research, which has a significant impact on its progress (Shchukin, 2008, p. 157).

The methodological substantiation defines universal approaches to research and at the same time reveals more specific propositions that serve as methodological guidelines which enable the linear or cumulative system of scientific knowledge. The development of knowledge goes in the direction of facts accumulation, their inductive generalization to theory (Pozdniak, 2006, p. 21). All components of the system are interconnected and outline the context within which a particular problem is being studied.

The methodological framework for modern scientific research is predominantly interdisciplinary. As Mogilnitskij argues, there is no single model of interdisciplinary synthesis, as there can be no single set of disciplines involved in it. It depends on the subject of the study and its scale (Mogilnitskij, 2002). Hence we propose that multidisciplinarity should be considered as a social paradigm of research in linguistics, pedagogy, other humanities, and social sciences, which determine the priorities of methodological relations in this scientific field.

Globalized and intercultural interaction of the humanities largely the integration of several specialties (e.g. linguistics with literary studies; social, ageappropriate pedagogy with linguistics) into separate scientific fields causes the need to create an interdisciplinary methodological framework for the study of specific objects. Therefore, methodological tools expand, complement each other, integrate through various approaches, methods, principles of different sciences, enabling deeper and more comprehensive analysis of the objects of research.

The purpose of this study is to create an interdisciplinary methodological framework for literary text analysis using the humanities approaches. 


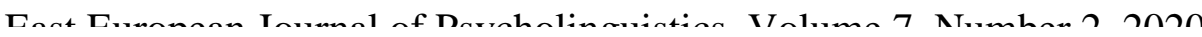

= Bohdana Labinska, Iryna Osovska, Oxana Matiychuk, Nataliia Vyspinska

\section{Methods and Materials}

The contemporary fairy tale Bunny Non-Hopper and His Brave Mommy by a Ukrainian writer and journalist Oksana Drachkovska (Drachkovska, 2019), is selected as the material for this research. Our choice was influenced by the relevance, innovativeness, importance, and complexity of the theme of the author's fairy tale, appearing in modern pedagogy and linguistics. Drachkovska's book is one of the very few fictional representations of so-called inclusive fiction in the contemporary Ukrainian literary world, raising the question of children's inclusion in the school environment. The tale, at first glance, is within the field of pedagogical and educational sciences. However, it is by no means limited to the walls of educational institutions and in recent years has gradually become a part of the scientific and public discourse in Ukraine.

Inclusion is a process of building close, interpersonal relationships among society members - those who are the "regular" majority and those who are "different" and have special needs. As a post-totalitarian society, Ukrainian society continued the tradition of isolation, segregation, and marginalization of people with physical or intellectual disabilities. More than twenty years have passed from the time of the adoption of the Salamanca Declaration (UNESCO, 1994) to the real steps towards the implementation of inclusive education in Ukraine ${ }^{1}$, and now one can speak only of its initial stage and gradual introduction of this topic into the broad public discourse. However, this process is of vital importance and, hopefully, irreversible, because "education determines the degree of the development of a state, while inclusive education determines the degree of the development of the society we live in. And this is [...] the level of humanity and tolerance for "those different from you" (Poroshenko, 2019).

It is well known that literature is a significant constituent part of the educational process. Fiction can provide everything a contemporary and a future person needs, regardless of the sphere of his/her activity: flexibility of thought, imagination, fantasy, feelings, empathy.

A very convincing argument for this gives the British writer Gaiman in one of his lectures. In 2007, he participated in the first party-approved science fiction and fantasy convention in China, and concluded that the event was of national importance and took place due to the inability of the Chinese to think innovatively:

"The Chinese were brilliant at making things if other people brought them the plans. But they did not innovate and they did not invent. They did not imagine. So they sent a delegation to the US, to Apple, to Microsoft, to Google, and they asked the people there who were inventing the future about themselves. And they found that all of them had read science fiction when they were boys or girls. Fiction can

\footnotetext{
${ }^{1}$ Much time has passed since the adoption of first legislative acts in Ukraine, ratification of international treaties, the publication of the first theoretical scientific works until actual implementation. The most important of them, which permit to trace the main stages of theoretical and practical development, are collected in the bibliographic guide.
} 
Fact Furnoman Inurnal of Devoholinmictice Volume 7 Numhar 7 on

Methodological Framework for the Interdisciplinary Literary Text Analysis :

show you a different world. It can take you somewhere you've never been. Once you've visited other worlds, like those who ate fairy fruit, you can never be entirely content with the world that you grew up in" (Gaiman, 2013).

High-tech creators, Silicon Valley scientists, founders of, for example, Amazon, SpaceX, or Microsoft are eager to confirm Gaiman's thesis about the important influence science fiction has made on them (Livni, 2018; Baer, \& Lebowitz, 2015).

However, reading from childhood does not only enhance the development of imagination and thinking. Gaiman mentions another essential skill namely social competence, for the development of which reading is also indispensable:

"And the second thing fiction does is to build empathy. When you watch TV or see a film, you are looking at things happening to other people. Prose fiction is something you build up from 26 letters and a handful of punctuation marks, and you, and you alone, using your imagination, create a world and people it and look out through other eyes. You get to feel things, visit places and worlds you would never otherwise know. You learn that everyone else out there is as me, as well. You're being someone else, and when you return to your own world, you're going to be slightly changed" (Gaiman, 2013).

German educators also emphasize the role of literary reading in literacy development, which is largely focused on purposeful acquisition and application of information (Hennies, Ritter, 2015, p.262). The experience of teaching in inclusive classrooms proves that the processes of forming meanings, which arise during the discussion of the story and are influenced, among other things, by the imagination and empathy of readers, their subjective use in the text and literary-aesthetic sensitivity to speech sound and rhythm, are of paramount importance (Hennies, Ritter, 2015, p.262).

Empathy is one of the competencies that are also indispensable in the implementation of the principles of inclusive education and understanding of special needs. The story for the youngest readers, proposed for analysis, aims to form, among other things, social and emotional empathy.

Given the specific nature of the topic, we believe that the combination of selected approaches in the fields of pedagogical and philological sciences will be especially productive for the research. The sequence of the article is determined by literary studies interpretation (to estimate the role of the story in similar Ukrainian and foreign literature and reveal some features of the fairy tale gender constructs); linguistic interpretation (to analyse the fairy tale using communicative-pragmatic and conceptual approaches that thoroughly focus on the text-discursive level); pedagogical interpretation (to select approaches which enable the representation of the educational potential of the text-discourse studied).

The general scientific level of this integrated interdisciplinary study consists of systematic, synergetic, and paradigmatic approaches.

The systematic approach facilitates the identification of all the constituent elements of the studied process or phenomenon; study of the relationships, the interdependencies among compound elements, and, thus, identification of the main 
elements with the leading relationships; construction of a model characterized by the three parameters: organization, integrity and hierarchy; disclosure of the dependence of the defined system on external conditions, since only then the system can function; description of a particular component in a continuous whole with the system, and, also, its general and specific functions within a single whole; identification of the properties of the studied process, including the sum of the properties of its constituents as well as the features and structure of the system itself. The systematic approach to the story ensures the complexity of the analysis embracing all the factors identified.

Synergetic approach, which emerged in the 60s and 70s of the XX century, declares the knowledge of the general laws and principles that form the basis of the processes of self-organization of complex systems of diverse nature as its main task (Gao, et al., 2014, p. 2). In particular, the principle of instability, a state of readiness of the system for changes and the moment of choosing their direction, means that at the point of unstable equilibrium (bifurcation point) the system is characterized by high sensitivity to weak signals, and the future of the whole system may depend on their accidental influence. The system becomes most sensitive to them only during certain stages of its development - during the periods of instability dominance over the stability of its structure when the system is already objectively forced to abandon the old trajectory of development, and the new one is just beginning (Nesterenko, 2006, p. 41). The principle of selforganization of systems is defined as a set of processes in the course of which the structure of the system is created, maintained, reproduced, improved, and which are aimed at preserving the integrity (Nesterenko, 2006, p. 43). According to the principle of self-reproduction of systems, preserving of parameters is a problem and task of the system itself, since all its functions are ultimately directed to its reproduction and restraining the growth of entropic (variable, rotated) processes (Nesterenko, 2006). The principle of resonance influence allows us to understand how to manage self-organized systems more effectively. Closely related to the synergetic ideas of multivariate evolutionary trajectory, choice of alternatives, irreversibility of progress and its pace is the principle of nonlinearity (Serezhnikova, et al., 2015, p. 149). According to this principle, the system can be restored by completing the old order and creating a new one, revealing an unexpected trajectory of systems' development which cannot be extrapolated from the linear deterministic analysis (Vozniuk, 2009, p. 11).

The synergetic approach is needed to analyse the problem of the study, as it reveals the principles of instability, self-organization of systems, non-linearity, etc., arising in the system of education with a socially significant problem - education of persons with special needs and requires creating conditions for adequate teaching. Functional orientation of the whole system towards the fulfilment of the main tasks - the formation of an educated person, preparing him/her for full social activity and, consequently, ensuring the transmission of culture to the next generation as well as the inclusion of each individual in this culture. 
applied components of the actual functioning system of a certain activity, we apply the paradigmatic approach to understand the integrative design of the story, its conformity, and adequate reflection of reality and specific life-educational conditions (Phoenix, et al.,2013).

To present specific research methodology, we need to consider current trends in two humanities we have chosen for the prism, which will determine the focus of the study - philology (linguistics and literary studies) and pedagogy.

\subsection{Literary Studies Approaches: Intertextual and Gender}

Among the many opportunities for analysis of the text used by contemporary Ukrainian literary studies, we choose, first of all, two, due to their novelty. Obviously, one can speak of the author's intention, which is to "encode" a multilayered associative series of titles for a Ukrainian-speaking reader. We will try to "decode" them using intertextual analysis and elements of feminist criticism.

Although literary studies in Ukraine began to introduce these approaches into active scientific circulation only since the early 1990s when Soviet ideological obstacles disappeared, there are now a number of works illustrating the scale of their use and the potential for new readings of Ukrainian literature and reception of foreign authors in Ukraine as well.

The theoretical basis of the intertextual approach was introduced by a Soviet scientist Bakhtin (Bakhtin, 2000), and became widely employed by Western literary critics Kristeva, Barthes, Bloom, Lachmann, Pfister, Allen. Many modern Ukrainian literary critics (Rykhlo, Dzera, Perelomova, Shapoval, and others) devoted their monographs to the issue of intertextuality. Researches on intertextual interactions at all levels of literary fiction have given a new impetus to the interpretation of classical works and literature prohibited for decades due to ideological issues, revealed the typological and genetic affinity of phenomena between literatures, the relationship between literatures, extended the theoretical basis, etc. The potential of intertextual analysis given the vast array of fiction that is invariably being updated with the new works is almost inexhaustible. Studies on the history of literature that deploy elements of intertextual criticism are prevalent in Ukraine.

The methodological tools for gender literary studies or feminist criticism (in Ukrainian discourse these terms are often used as identical) became available to national literature critics in the post-Soviet era. Ageeva (Ageeva, 2003), Uliura (Uliura, 2015), Zborovska (Zborovska \& Ilnytska, 1999), Hundorova (Hundorova, 2002), Filonenko (Filonenko, 2006), and others use the approaches of feminist criticism in their scientific works.

The two starting points of gender studies were the works of Simone de Beauvoir "Le Deuxième Sexe" and Kate Millett's "Sexual Politics", and various aspects were revealed by Butler, Gross, Moy, Walker, and many others. In Ukraine in the early 1990s, "a prominent figure in this sense was Pavlychko" (Plakhotnik, 2011). However, "the actual equation between feminist and gender approaches to the study of literature, the lack of a clear understanding of the tasks and the 
Bohdana Labinska, Iryna Osovska, Oxana Matiychuk, Nataliia Vyspinska

national discourse "amorphous" (Shaf, 2018).

In our paper, we employ feminist criticism to analyse the key character of the story - Mommy Bunny, since it combines stereotypical feminine traits and signs of a non-classical female gender.

\subsection{Linguistic approaches: communicative-pragmatic and conceptual}

Philological analysis of the studied text encompasses communicativepragmatic and cognitive-discursive paradigms of modern linguistics.

The communicative-pragmatic approach was formed in the 60-70s of the XX century on the principle of integrative anthropocentricity, system-centricity, and functionality, where idea moves from functions, notions, communicative goals, and intentions to the means available in the language (Susov, 2007, p. 29). The main unit of verbal communication is a speech act - an expression in its procedural aspect, the sequence of speech acts forms a discourse - "live" event of reality. The communicative-pragmatic method is presented as an interdisciplinary integration of the methods, techniques and procedures aimed to study how a speaker uses language in the process of communication in combination with the pragmatic properties of linguistic units manifested in the situation of communication, to achieve success, regulate linguistic (and not only linguistic) behaviour of a person and coordinate his/her activities. The communicative-pragmatic analysis of the text exposes its compositional, semantic, and pragmatic properties defining the type of the text, its theme, structure, lexical grammatical outline, features of intertextual relations, stylistic means, pragmatic essence, features of communicative linguistic behaviour, intentions, strategies, and tactics (Samender, 2016).

Linguistics is now undergoing the formation of the cognitive (or cognitivediscursive) paradigm (Maslova, 2008, p. 9; Golovanova 2011, p. 6; Sirojiddinov \& Normurodova, 2019; Leezenberg, 2009; Ito, 2013). Its main task is to build a model of language communication as a basis for knowledge sharing (Maslova, 2008, p. 12). Each object is subject to multivariate analysis (Luzina, 2008, p. 43) and the cognitive method is considered to be interdisciplinary integrity of the methods, techniques, and procedures used to study the linguistic representation of mental processes and their results, shaped in the human mind in the form of knowledge. The basic unit of knowledge is a concept, which analysis methods are different: profiling, Gestalt approach, description through images, pictures, schemes, description of core-peripheral structure, description through the container model, description of the interlayer structure of a concept (Maslova, 2008, p. 113-119). The most popular methods are conceptual analysis (Boldyrev, 2004, p. 26) (focuses on the expression of meanings conveyed by individual words, phrases, typical sentences ..., as well as individual texts and even whole works (Jackendoff, 1996) and cognitive analysis that integrates the methods of category analysis (Rosch's prototype semantics, Langacker's cognitive grammar, Fillmore's frame semantics, Jackendoff's cognitive semantics) and views categories as conceptual sets of objects or sets of objects based on a common concept (Hart \& Lukeš, 2009). 


\section{Methodological Framework for the Interdisciplinary Literary Text Analysis}

identification of the specifics of its conceptual-communicative palette.

\subsection{Pedagogical Approaches: integrated, inclusive, humanistic and empowerment}

The integrated approach in the education system incorporates the creation of a single educational space where general and special education, as well as the education of children with psycho-physical disabilities, converge. It is quite common to associate "integration" with mainstreaming where a child is in a group with other pupils most of the time and segregated only for a while in a specially adapted environment. It is believed that in this way children will accept the rules, comply with them and be equal with everyone. However, to achieve this they have to put considerable effort and time to adapt to the environment (Kuzava, 2015, p. 120; Úcar, 2013).

The inclusive approach to education implies respect, understanding and assurance of diverse activities (education system, teachers, students), as well as real equal access to the educational institutions for every child without exceptions. It is important to realise the idea of "inclusion" in the educational process, the socialization of a child, not out of pity or charity, but in the interests of society, guided by regulatory documents. Therefore, it is quite legitimate to claim that the inclusive approach is a strategy based on the theoretical principles of inclusive education, which involves joint training and education of people with different mental and physical abilities on the basis of equality of rights and tolerant attitude towards each other (Kuzava, 2015, p. 118-119; Florian \& Black-Hawkins, 2011).

The humanistic approach is person-centred since a person is the highest value of society and has a sufficient degree of freedom to choose his/her pursuits. In particular, the philosophy of existentialism offered a new perspective on persons with disabilities, their individual, and social existence. The central premise of existentialism is existence (from Latin existentio), the central core of the human being, according to which each individual is a unique and free person held responsible for his/her actions (self-esteem) and the surrounding world (social interaction skills) (Nazarova, 2010). Inclusive education of children with psychophysical development peculiarities is a higher degree of integration, where all educational institutions and educational philosophy adapt to the needs of all children. It is a kind of approach that seeks to develop a child-centred methodology meeting various educational needs. The inclusive approach involves a wide range of actions and initiatives (in particular, creating opportunities to fully meet the children's needs), while integrated learning enables creation of special conditions in the current education system for such persons (Lemberger \& Hutchison, 2014).

For this study, we also employ empowerment - a direction of pedagogical research based on giving motivation and inspiration to act. It was developed by Swedish academic Mellander, who applied the ideas of Johnson, JohnsonHoloubek, Dewey, Kolb, Latyshyn, Radugin, Fokin to form an educational cycle that became one of the areas of the humanistic pedagogy of empowerment. 
Bohdana Labinska, Iryna Osovska, Oxana Matiychuk, Nataliia Vyspinska

responsibility for its results, gaining the ability to monitor, and control learning processes, generating enthusiasm and a sense of satisfaction from the group and individual work and its results. Empowerment is a support language aimed at the awakening of internal energy (Vovk \& Zhukova, 2016, p.40).

The main aims of empowerment are to create the conditions for a child to develop confidence in his/her abilities and responsibility for learning outcomes, ensuring psychological comfort for children in a class, employing special methods and content capacity (every child can choose which steps to take), creating conditions for enthusiasm and satisfaction from the group and individual work, performing actions and building behavioural models focused on sustainable development, achieved primarily via constant positive (both in form and content) feedback (Harmony Child Development Centre, 2017).

The proposed interdisciplinary methodological framework for literary text analysis allows illustrating the formation and reception of the mentioned notions. Intertextual and gender approaches provide opportunities for the reception, based on possible and/or present experience of a Ukrainian-reader. Communicativepragmatic and conceptual linguistic approaches help identify the main strategictactical and conceptual text formats of the discourse. To reveal the educational potential of the story we apply modern pedagogical approaches.

\section{Results and Discussion}

\subsection{Literary Studies Interpretation}

The difficult topic of "otherness" in Ukrainian literature, which is central to Drachkovska's story, has existed for a long time, as in other national literatures. However, it is different and new, as it "aims at perceiving personal diversity" (Inclusive Ambassador Network) by the readers and forming their positive attitude towards those who, by some criteria, are labelled as "different", "special", and it does not aim to be sympathetic or sorry for them. Over the last four years, more than two dozen works of inclusive literature have appeared, for example, on the portal Inclusive Ambassador Network.

The thematic range of special topics for more mature readers is complemented by numerous translations into Ukrainian of works by foreign authors, such as Alan Marshall's "I Can Jump Puddles", Andreas Steinhöfel's "The Center of the World", Raquel J. Palacio's "Wonder", Daniel Keyes's "Flowers for Algernon", "The Gray House" by Mariam Petrosyan, Audhild Solberg's "Who is Against the Supercool". Even this small list illustrates a wide range of authors' geographical origins and the variety of topics through which they reach contemporary readers.

At the beginning of 2020, "Literature and Inclusion" by Derkachova and Ushnevich was published, which included selected works of foreign and Ukrainian inclusive literature. This is an innovative pedagogy proposal for the use of fiction in inclusive education. 
The fairy tale "Bunny Non- Hopper and his Brave Mommy" is a kind of

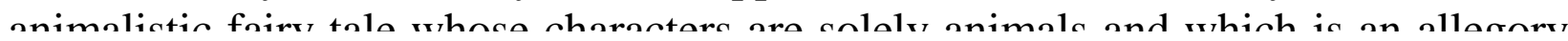
Methodological Framework for the Interdisciplinary Literary Text Analysis

which is known to Ukrainian readers from kindergarten. It is a poem "In the dark dark woods" ("A Song of the Christmas tree") written by Nehoda in Soviet times, which has become one of the essential attributes of New Year celebrations. It is about "Bunny Hopper" - an invariable character of New Year's holiday in Ukraine whom Santa Claus (Ukrainian: Did Moroz) takes to the New Year's party. In the title of Drachkovska's book, we observe the phenomenon of the negation of the property, which is understood as an immanent feature of this animal, associated with its intrinsic ability to jump. A simple word-making decision to use the negative prefix "non" for the diminutive "bunny" causes the recipient's perception ambiguity: on the one hand, the character invokes specific associative connections and contextual assumptions, on the other - it is identified by an atypical trait, and thus is absolutely different from a collective image of this animal, whose image may already be formed in the mind of an experienced reader. Bunny Non-Hopper does not have a proper name (like the rest of his large family), and in this case, the negative form plays the role of an anthroponym that evokes unambiguous connotations. "Only then has a proper name a certain meaning for the participants of a communicative act when the named object is well known to them. Consequently, it may receive some additional connotations. To be able to name and identify the character, the proper name must refer to the most essential characteristics of its medium in the recipient's mind" (Slavova, 2002, p. 48).

The title of the story as a para-textual element, as defined by Genette and Hoek, "is an artificial object, an artefact of reception or commentary" (Genette, 1997, p. 55-56), it conveys "many appended bits of information" (Genette, 1997, p. 56). In the case of the Drachkovska's tale, the extra connotations are formed not only because of the neo-logistical "non-hopper" but also the second component of the title - "his brave mommy". Here we find the second hidden negation of the implicit meaning: bunny as a fairy-tale hero provokes in a Ukrainian reader a set of associations primarily as a cute, fast, active but timid and defenceless animal: a "fairy tale bunny" is a model of "humility and defencelessness" (Pokhodenko, 2012 , p. 114). Therefore, "brave" in relation to the mother-bunny also forces the recipient to rethink the implicit features of this traditional fairy-tale image: the author goes beyond the stereotypical model often used in the fairy-tale genre.

It is especially interesting to observe Mommy Bunny character development: initially, it appears typically feminine, her reaction to the diagnosis of the doctor Owl that the bunny will never be able to hop, is classically female: "mommy cried" (Drachkovska, 2019); this emotional state is prolonged, as the reader learns, it does not change until the next day when daddy successfully tested his hand-made wheelchair and pushed the Bunny around the lawn: "Even mommy stopped sobbing and smiled" (Drachkovska, 2019). Another stereotyped element is the behaviour of Mommy Bunny, who, when getting dressed to the Forest Board, "put on her best dress" (Drachkovska, 2019). We can talk about a gender construct that 
reflects societal stereotypes (Ermolayeva \& Schwab, 2017). As classified by

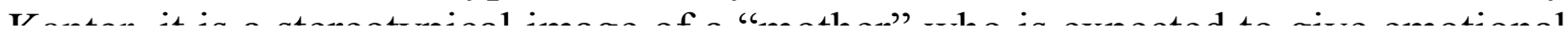

Bohdana Labinska, Iryna Osovska, Oxana Matiychuk, Nataliia Vyspinska

because "Mommy Bunny was comforting and entertaining all day" - not an active position, or, according to Ukrainian social realities and Kis's typology - an icon of femininity known as Berehynia (Kis, 2003). It should be noted that gender stereotyping is consistently and clearly reflected and illustrated. The author of the drawings, Drachkovska Junior demonstrates proficiency in modern illustration techniques, colour, and visual solutions. The most prominent gender marker for masculine and feminine characters is primarily clothing: men suits, ties, and pants and shirts versus skirts, dresses, and necklaces. The standard image of societal and gender stereotyping is an illustration depicting the Mommy Bunny in the Forest Board: notwithstanding the Mouse, who has business-style women's clothing on and presumably is a secretary, she is one of the twelve characters wearing a dress. All other characters are male, gender disproportion reflects, as we believe, another rooted stereotype, and often a real picture of male-dominated governance structures. The plot of the fairy tale also visualizes traces of bureaucracy of the institution and bureaucratic indifference: "Animals wearing business suits and carrying multiple folders and sheets of paper were seen everywhere. No one noticed Mommy Bunny, passing her deftly in the narrow passageways" (Drachkovska, 2019).

The metamorphosis experienced by Mommy Bunny destroys the original stereotyped idea that may emerge at the beginning of the story: from the classical mother role, she assumes "the role of social mediator" (Rana, 2017, p. 38) and becomes a social activist who is fighting for the rights of children with special needs, helping create conditions for their education and a barrier-free environment: "taking care of her son, she decided not to stop and help other forest animals. Thus, the first lift was installed in the forest - in the tree where the squirrel with injured paws lived [...] in the main forest street a sound traffic light was installed, and the blind hedgehog could now safely cross it" (Drachkovska, 2019). Inner experiences, motivational beliefs, or psychological factors that contribute to the evolution of this character are completely omitted in the story, as well as - and this may be the only compositional and structurally weak point that can be indicated - any rationale for the cause and effect of events, which facilitated the successful resolution of the request that Mommy Bunny had made to the Chairman of the Forest Board, who understood that "this lady is not kidding and has to be listened to very attentively" (Drachkovska, 2019) is absent. On the tale level, the author uses ellipsis techniques, and the reader immediately learns that just in a few days animals begin to build a bridge on which students and Bunny Non-Hopper will be able to get to the forest school in a wheelchair and that the efforts Mommy Bunny had made were highly successful. Such decision of the author, however, results in the omission of an important content element that is also present in the fairy tale genre: overcoming obstacles to achieve the goal, especially, considering the fact that in the real world 
the struggle for creating an inclusive environment means a confrontation with numerous problems and often misunderstandings from society.

nhrimulv

Methodological Framework for the Interdisciplinary Literary Text Analysis

tales as well as ancient folktales tend to generalize, stereotype, simplify meanings, and images. In Drachkovska's fairy tale, we have a happy ending, typical for this genre; however, we state that the specificity of the theme and the clear didactic focus of the work could deepen another, socially critical dimension, providing a more differentiated picture of difficulties and obstacles.

Drachkovska's story will undoubtedly raise questions and reflections in a young recipient, who seeks a dialogue with an adult to hear explanations of things and phenomena that are yet to be experienced. However, this is a perspective on the perception of a regular, "normal" child, whom the fairy tale presents a mini-model of a family and community facing the challenge of meeting the special needs of one of its members. Therefore, the other special inhabitants of society become "visible" against the background of normal society and also get a chance for a more fulfilling life.

\subsection{Linguistic Interpretation}

Linguistic interpretation allows to demonstrate certain communicativepragmatic and cognitive-discursive features of the text-discourse.

The communicative-pragmatic analysis shows the presence of communicative acts, first of all assertives (all new-born bunnies looked like tiny bundles) as they predominate in narratives, but also directives (we need a bridge over the stream near the school; well, it's time we went) and expressives (welcome everybody). Most communicative acts are explicit with distinct markers of linguistic action. Regarding strategic and tactical configurations, narrative and cooperative strategies predominate, which corresponds to the genre affiliation of the text. We note the absence of a manipulative strategy, which is widely common in most texts, obviously due to the age-specific and educational purpose of the tale. The communicative and pragmatic outline of the text highlights the communicative roles of "an active business mom", "caring father", "a child with special needs", "fair leader" which are motivated by social environment and reproduce typical strategic-tactical configurations, conventional language acts and their markers.

The cognitive-discursive paradigm allows to consider the analysed story to be an example of a fairy-tale discourse - the thinking and speech activity of fantastic events and characters. From this perspective, it is seen as a space in which specific cognitive domains and discursive concepts are activated within: family (MOTHER, FATHER, CHILD, BROTHERS AND SISTERS), movement / process / action (BIRTH, DREAM, HOPPING, CRAFTING, RIDING, PUSHING, LOWERING, LIFTING, CONSTRUCTION, GAME, CARRYING ON SHOULDERS, RESTLESSNESS), mental activity (DREAMING, IMAGINING, IMMERSION IN THOUGHTS, TO COMPREHEND, TO FEEL), defects (ILL, BLIND), verbal activities (EXPLANATION, COMFORTING, BODY LANGUAGE), physiology, social activity and collaboration (GREETINGS, LISTENING, TEAM, FRIEND, 
HELP), social sector (DOCTORS, TEACHERS, LESSON, BELL, FOREST BOARD, FOLDER, ASSESSMENT, CLASSROOM, SUBJECT, RESCUE

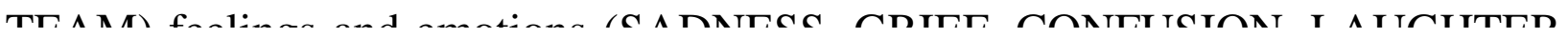
Bohdana Labinska, Iryna Osovska, Oxana Matiychuk, Nataliia Vyspinska

BOISTEROUSNESS, IRRITABILITY, RUDENESS), qualities and features (INTELLIGENCE, OBSERVATION, CREATIVITY, EFFICIENCY, CHEERFULNESS, TALKATIVENESS, PRUDENCE, OBEDIENCE) things and objects (WHEELCHAIR, LIFT, TRAFFIC LIGHTS), place and time, clothing (SUIT, DRESS, SHOES), landscape (STREAM, GREAT GULLY, DEEP WOODS, STREAM, PATH, WAY, ROUTE, BANK, OBSTACLE, HILL, FOREST, DELL, LAKE, THICKET), buildings (HOME, SCHOOL, BRIDGE, MOTORWAY), leisure activities (SPORT, RELAY, SCOUTING, THEATRE CLUB, STAGE, ACTOR, ADVENTURES, RIDING, HIKING).

The defined concepts form the stable characteristic of this kind of discourse relations between the established information categories: inclusion (man (personified animal) $\epsilon$ physiology (when it was time for the kids to jump a little, it turned out that one bunny wasn't able to do it), person $\epsilon$ character trait (like all kids, Bunny Non-Hopper was a little imp and took active part in various adventures), person $\epsilon$ emotions and feelings (Mommy Bunny and Daddy Bunny were very upset; mommy was crying, daddy was deeply worried), man $\epsilon$ social sphere (the doctor quickly arrived .. checked the Bunny), person $\epsilon$ leisure (daddy took his tool box from the pantry and started doing something), movement $\epsilon$ obstacle (it was not even a large stream, the bunnies crossed it easily, jumping from stone to stone: but even with daddy's help the wheelchair could not overcome this obstacle), social cooperation $\epsilon$ help (when the trail ended, all bunnies carried Bunny Non-Hopper on their shoulders taking turns), causation (action $=>$ emotion (daddy put the bunny in it and started pushing it around the lawn, the bunny laughed with happiness), physical defect $=>$ facilities (so the first lift appeared in the forest - in the tree where the squirrel with injured paws lived. And then a sound traffic light was installed on the main forest street, and the blind hedgehog could now safely cross the street), coordination (citizens $\leftrightarrow$ authorities (Animals wearing business suits and carrying multiple folders and sheets of paper were seen everywhere. Nobody noticed Mommy Bunny, passing her deftly in the narrow passageways), creativity $\leftrightarrow$ physical defect (when he recited monologues during the performances, everyone stood transfixed, and nobody seemed to notice that the young actor was sitting in a wheelchair), consequence (a child $\rightarrow$ a school (the Bunny dreamed of attending forest school), event $\rightarrow$ experience (since then the Bunny became more prudent and obedient), problem $\rightarrow$ action (the mother's heart felt and understood everything... and the next day she put on her best dress and went to the Forest Board; later, forest school teachers learned body language and several animals with hearing impairments also became students).

The analysis (including quantitative) of discourse-forming concepts and the connections between them suggests that the researched contemporary social moral- 
ethical fairy-tale discourse has a regular conceptual system, which attests to the relevance of personal (physiological and emotional) and social information, whose elements enter into many permanent inter-conceptual relations creating its unique

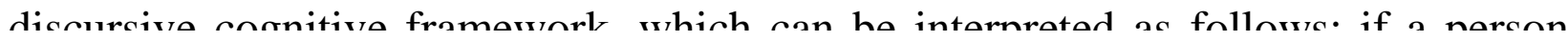
Methodological Framework for the Interdisciplinary Literary Text Analysis

realized the uniqueness of one of its members and tries to create all the necessary conditions, tackling many related elementary household and social issues, using ingenuity and skills, he/she will be realized and be able to discover his/her talents and feel happy.

Linguistic paradigms-specifiers, as well as individual linguistic branches (dialectology, etymology, onomastics, linguostylistics, applied linguistics, etc.) that create multiple methods (sociolinguistic, ethnolinguistic, linguistic geography, psycholinguistics, neurolinguistics, paralinguistic method, linguistic-cultural, intercultural communication, etc.), could provide additional angles of the studied story, but this is a topic of another research.

Thus, it can be argued that the studied story, despite the traditional genre modification of modern moral and ethical fairy tale, represents and emphasizes the important problem of the present, engages a reader in reflection, empathy, and, consequently, makes readers co-participants, projecting their possible response to a specific social problem in the future.

\subsection{Pedagogical Interpretation}

The pedagogical interpretation of the study allows us to draw some conclusions from the standpoint of general scientific and specific scientific approaches.

From the standpoint of a systematic approach, we conclude that in the autobiographical fairy tale story for children by Drachkovska's, "Bunny NonHopper and his Brave Mommy" the constituent parts are the family and children/students, teachers of the school, and the phenomenon - the disability of a child. The dependency of each of the elements, that is, the help of each fairy tale character - parents, siblings provides the opportunity to Bunny Non-Hopper to go to school, gain the education, that is, develop and socialize properly. Mommy Bunny, applying to all the necessary administrative institutions (in the fairy tale, of course, they were all imaginary - Doctor Owl, the Forest Board) tries to do everything possible so her son, Bunny Non-Hopper, could get a decent education. All the efforts - wheelchair building by Daddy Bunny, mommy's help in tackling issues in eligible institutions, support of siblings, their kindness, responsiveness, and desire to help contribute to the main goal - to study at school with all children in equal conditions. In this case, all the elements of the system converge to solve the problem in the autobiographical story.

Analysing the methodology of the systematic approach to the fairy tale story about a child with special educational needs, we consider statements that will help establish the properties of the system objects: teaching a child with special educational needs is a relatively independent range of issues, but is studied in close connection with the social order of a society, goals of education and training, content, principles of learning; the system of education in primary school is 
regarded as a multilevel hierarchical structure, within which the nature of the interaction of all its elements is determined.

In this fairy tale, a number of principles of the synergetic approach are Bohdana Labinska, Iryna Osovska, Oxana Matiychuk, Nataliia Vyspinska

students, but a new trend in education is only emerging and adequate learning conditions have yet to be created. The principle of self-organization of systems is reproduced in the self-organized system, which is caused by social needs, supported by the Ministry of Science and Education of Ukraine, implemented in the institutions of secondary and higher education, being improved by scientific research and experience of teachers and preserves the integrity of the education system in Ukraine. The principle of self-reproduction of systems is seen in a study where a self-organized system of teaching students with special educational needs in primary school is transferred to education in secondary and senior school, where their problems and tasks become important for further education of people with special educational needs. Another important principle - the principle of resonant influence, which helps to understand how to manage self-organized systems more effectively, is manifested through the actions of the protagonist's mother - Mommy Bunny, who had the courage and great patience to apply to the eligible administrative institutions (in the fairy tale - the Forest Board) and obtain the right to have her child educated and have adequate conditions created (such as the bridge over the stream, the first lift in the woods, the sound traffic light) so he (and later other children with special needs) would be able to attend school. In addition, caring friends, classmates help Bunny Non-Hopper, despite his physical disabilities, to get to school in the wheelchair, carry him on their hands during the trips, disregard the wheelchair, enjoying his monologues in a theatre club and more. In the text we also notice the reproduction of the principle of non-linearity, because the unexpected trajectory is that the bunny has the opportunity to go to school, his dream to attend school with his sisters and brothers and acquire knowledge comes true. Gradually, the Bunny learns how to wheelchair and participate in all active games with his siblings, lead a lifestyle similar to other children. Teachers learn body language which helps them in selecting the right forms of work for children with special educational needs.

The paradigm approach is reproduced in the description of the educational institution - the school, with its inherent model of learning. It is worth considering whether the educational system is already established and practices according to the general philosophical and methodological categorical and special conceptual bases, which can be regarded as the one that is representing its model, or it is still in the mode of innovative search and developing. In this fairy tale story that, actually, virtually depicts the real problems in the organization of educational conditions for students with special educational needs, describes lessons in Physical Education, Language and Literature, theatre club, teachers' mastering of new approaches, principles, and methods for professional skills.

The integrated approach in our study is the right and the ability of the main character to study at school with all students, to take an active part in all types and 
forms of social life alongside and equally with others, and the readiness of an educational institution to accept a child with special educational needs, to develop

Methodological Framework for the Interdisciplinary Literary Text Analysis

educational system, while inclusion involves adapting the education system to the needs and capabilities of each individual, which is an important requirement for quality education.

Through empowerment, we interpret the fairy-tale character Bunny NonHopper, who embodies a student with special educational needs in real life, as an active creative personality with inner strength, energy, the inspiration to act, who can learn and develop in different forms of learning, get high grades in all subjects, to wheelchair skilfully and play basketball well, to participate in performances. At the same time, the main task of the teacher for such a student is the desire to promote self-study, to encourage, to guide a child in his/her efforts, which is traced through the successful learning results of Bunny Non-Hopper. An important empowerment approach is to motivate the learner to do each follow-up task or activity which arises from the information about the results and purpose of the previous actions. In this learning process, the teacher plays the role of a master who sets an example of behaviour and develops students' thinking, creativity, and communication skills. Task giving leads students to find independent solutions. They use the knowledge they have gained to face new challenges and make the next steps.

Thus, the theoretical and methodological verification of the literary text analysis is interdisciplinary, based on literary, linguistic, and pedagogical spheres and, accordingly, integrates a number of interdisciplinary approaches that outline the contours of the study (see Table 1).

Table 1.

Methodological framework for the interdisciplinary literary text analysis

\section{Research projections Methods/methodological}

approaches

\begin{tabular}{|c|c|}
\hline \multicolumn{2}{|c|}{ General scientific level } \\
\hline & - systematic \\
\hline Literary Studies, Linguistics, & - synergetic \\
\hline Pedagogy & - paradigmatic \\
\hline \multicolumn{2}{|c|}{ Specific scientific level } \\
\hline Literary Studies & $\begin{array}{l}\text { - intertextual } \\
\text { - gender }\end{array}$ \\
\hline Linguistics & $\begin{array}{l}\text { - communicative and pragmatic } \\
\text { - cognitive-discursive }\end{array}$ \\
\hline \multirow[t]{4}{*}{ Pedagogy } & • integrated \\
\hline & - inclusive \\
\hline & • humanistic \\
\hline & - empowerment \\
\hline
\end{tabular}




\section{Conclusions}

Bohdana Labinska, Iryna Osovska, Oxana Matiychuk, Nataliia Vyspinska

needs. Literary studies, linguistic, and pedagogical methodological guidelines serve as an intellectual scheme of consistency and interaction of approaches, methods, principles. The set of methodological approaches used in the study should not include mutually exclusive approaches. The methodological approaches used in the study should complement each other, permitting to consider and study the particular object in a comprehensive and interrelated way. Integrating knowledge of the various sciences, incorporating the specifics of each, the interdisciplinary methodological framework performs system-building function aimed to obtain comprehensive information about the object of the study.

Every science has the general scientific level of research. It has the status of universality and is a component of cognitive processes intrinsic to any field, the results of its knowledge constitute the methodological canvas of a science. Consequently, from a synergetic perspective, we consider the analysed text as a complex system that develops structurally, cognitively-discursively, communicatively-pragmatically, self-organizes, re-organizes itself intertextually by the interaction of elements and parts of the whole, and can be analysed through the synthesis of the humanities.

The paradigmatic approach allows us to present a text as a verbal representation of the problem-solving model, as an interdisciplinary object that thematises and problematizes the specifics of academic requirements for children with special educational needs.

The specific scientific level served as a presentation of specific approaches to each field of knowledge, with specific guidelines and means of expression.

The literary studies approaches allowed to outline the thematic context of a fairy tale work in literary production on "otherness" and its perception and to find some intertextual connections, especially with the source to which the title appeals. There are stereotyped constructions, the presence of which is conditioned by the genre and age of the primary target group (children of preschool and primary school age) and, it is possible, partly by deep-rooted stereotyped perceptions of gender roles in Ukrainian society and the innovativeness of the author's approach to the building of the key character Mommy Bunny, which is, as we assume, a consequence of the biographical situation, since the author herself is the mother of a child with special educational needs and social activist fighting for the rights of children with special educational needs, but, also, the creative intent of an experienced journalist who is aware of gender inequality issues and seeks to draw attention to the opportunities and activities of contemporary women in Ukrainian society.

Linguistic projection, represented by communicative-pragmatic and cognitivediscursive approaches, enabled us to find in the text the main cognitive properties 
of the studied discourse, which outline the awareness of the problem by the speaker and form the necessary mental framework for its understanding, which mirrors his/her/their actual behaviour in this type of discourse.

Tha nadomonimal narenantiva allowrad we to monoluda that tha calantad

Methodological Framework for the Interdisciplinary Literary Text Analysis :

revealing the content of the autobiographical fairy tale story. The system of research actions and procedures of scientific explanation of pedagogical reality revealed normative and descriptive functions, features of education and training processes, allowed to systematize the whole volume of scientific knowledge, and create the conditions for the development of further effective directions of research.

The result of the integration of these approaches is the methodological framework for philological and pedagogical in-depth analysis of the literary text.

\section{References}

Агеєва, В. Жіночий простір: Феміністичний дискурс українського модернізму: Монографія. Київ: Факт, 2003. 320 с.

Бахтин М. Эпос и роман. Сборник. Санкт-Петербург: Азбука, 2000. 304 с.

Болдырев Н. Н. Концептуальное пространство когнитивной лингвистики. Bonpocы когнитивной лингвистики. 2004. № 1. С. 18-36.

Вовк Н. В., Жукова М. В. Застосування педагогіки емпауерменту в проектній діяльності учнів на уроках трудового навчання. Наукові записки Тернопільського національного педагогічного університету імені Володимира Гнатюка. Серія: педагогіка. 2016. № 2.

URL: http://dspace.tnpu.edu.ua/jspui/bitstream/123456789/6888/1/VOVK.pdf

Вознюк О. В. Розвиток вітчизняної педагогічної думки: синергетичний підхід. Житомир: Вид-во ЖДУ ім. I. Франка, 2009. 184 с. URL : http://eprints.zu.edu.ua/id/eprint/4036

Голованова Е. И. Особенности категоризации и концептуализации специальных знаний. Введение в когнитивное терминоведение. Москва: Наука; Флинта, 2011. С. 104-139.

Гундорова T. Femina melancholica: стать і культура в гендерній утопії Ольги Кобилянської. Київ: Критика, 2002. 273 с.

Єрмолаєва Т. В., Шваб К. В. Гендерні стереотипи у сучасному українському суспільстві. Вісник Університету імені Альфреда Нобеля. Серія Педагогіка і Психологія. 2017. № 1(13). C. 92-96. URL: http://ir.duan.edu.ua/bitstream/123456789/2900/1/15.pdf

Зборовська Н., Ільницька М. Феміністичні роздуми: на карнавалі мертвих поцілунків. Львів: Літопис, 1999. 336 с.

Зязюн I. Цілісний методологічний підхід у педагогічному науковому дослідженні. Професійне становлення особистості: проблеми $i$ перспективи: матеріали IV міжнародної науково-практичної конференції. Хмельницький, 2011. С. 7-13.

Кісь О. Моделі конструювання гендерної ідентичности жінки в сучасній Україні. Незалежний культурологічний часопис «ё». 2003. № 27. С. 37-58. URL: http://www.ji.lviv.ua/n27texts/kis.htm

Коваленко І. Ю., Баранова, С. В. Анімалістична казка як вид казки. Молодий вчений. 2016. № 11(38). C. 198-201. URL: http://molodyvcheny.in.ua/files/journal/2016/11/46.pdf

Краевский В. В. (2009). Науки об образовании и наука об образовании (методологические проблемы современной педагогики). Bопросы философии. 2009. № 3, 77-82. URL : http://www.kraevskyvv.narod.ru/papers/nauki.htm

Кубрякова Е.С. Парадигмы научного знания в лингвистике и её современный статус. Серия литературы и языка. 1994. Т. 53, № 2. С. 3-15. 
Кузава І. Б. Методологічні основи дослідження проблеми інклюзивної освіти дітей дошкільного віку. Педагогічні науки: теорія, історія, інноваційні технології. 2015. № 6(50). C. 116-127. URL : http://nbuv.gov.ua/UJRN/pednauk_2015_6_18

Лузина Л. Г. О когнитивно-дискурсивной парадигме лингвистического знания. Парадигмы

Bohdana Labinska, Iryna Osovska, Oxana Matiychuk, Nataliia Vyspinska

Мережа інклюзивних амбасадорів. Inclusive books. https://inclusivebooks.org/index.php

Могильницький Б. Г. Междисциплинарный синтез: уроки школы Анналов. Методологический синтез: прошлое, настоящее, возможные перспективы. 2002. C. 10-42. URL : http://klio.tsu.ru/annals.htm

Назарова Н. М. Интегрированное (инклюзивное) образование: генезис и проблемы внедрения. История и Теория. Сочиальная педагогика. 2010. № 3(9). С. 77-87. URL : https://cyberleninka.ru/article/n/integrirovannoe-inklyuzivnoe-obrazovanie-genezis-iproblemy-vnedreniya-1/viewer

Нестеренко Г.О. Синергетичний вимір нації та націєгенези. Філософські науки: Збірник наукових праџь. 2006. С. 40-46.

Плахотнік О. Неймовірні пригоди гендерної теорії в Україні. Критика. 2011. URL : https://krytyka.com/ua/articles/neymovirni-pryhody-gendernoyi-teoriyi-v-ukrayini

Поздняк С. Н. Становление и тенденции развития методики обучения географии как науки в России: дис. ... докт. пед. наук: 13.00.02 / Уральский государственный педагогический университет, 2006. $411 \mathrm{c}$.

Порошенко М. А. Інклюзивна освіта. Київ: ТОВ «Агентство Україна», 2019. 300 с.

Походенко С. Герої українських народних казок в архетиповій свідомості суспільства. $\begin{array}{llllll}\text { Психолінгвістика. } 2012 . & \text { № } 9 . & \text { C. } & 106-117 . & \text { URL: }\end{array}$ http://nbuv.gov.ua/UJRN/psling_2012_9_17

Славова М. Попелюшка літератури: теоретичні аспекти літератури для дітей. Київ: ВПЦ «Київський університет», 2002. 81 с.

Сусов И. П. Введение в теоретическое языкознание. Москва: Восток-Запад, 2007. 379 с.

Улюра Г. Пострадянська жіноча проза як соціокультурний та естетичний проект (на матеріалі російської літератури). Київ: Ніка-Центр, 2015. 608 с.

Філоненко С. Концепція особистості жінки в українській жіночій прозі 90 х років XX століття: Монографія. Київ, Ніжин: ТОВ “Видавництво “Аспект-Поліграф, 2006. $156 \mathrm{c}$.

Центр розвитку дитини “Гармонія". Освіта для сталого розвитку - новий напрям у сучасній освіті. 2017. URL: http://www.garmoniya.mk.ua/articles/osvita-dlya-stalogorozvytku-novyy-napryam-u-suchasniy-osviti.html

Шаф О.В. Гендерне літературознавство в Україні: теоретико-методологічні зауваги. Науковий вісник міжнародного гуманітарного університету. Серія Філологія. 2018. № 37 (1). C. 83-86. URL: http://www.vestnik-philology.mgu.od.ua/archive/v37/part_1/24.pdf

Щотка О. П. Гендерна психологія. Ніжин, 2019. 358 с.

Щукин А. Н. Лингводидактический энциклопедический словарь: более 2000 единиц. Москва: Астрель, 2008. 746 с.

Baer, D., \& Lebowitz, Sh. (2015). 14 books that inspired Elon Musk. Business Insider, 10. Retrieved from: https://www.businessinsider.com/elon-musk-favorite-books-2015-10

Florian, L., \& Black-Hawkins, K. (2011). Exploring inclusive pedagogy. British Educational Research Journal, 37(5), P. 813-828. https://doi.org/10.1080/01411926.2010.501096

Gaiman, N. (2013). Why our future depends on libraries, reading and daydreaming. The Guardian, 15. Retrieved from: https://www.theguardian.com/books/2013/oct/15/neilgaiman-future-libraries-reading-daydreaming 
Gao, S., Zhang, H., \& Liu, H. (2014). Synergetic properties of Chinese verb valency. Journal of Quantitative Linguistics, 21(1), 1-21. https://doi.org/10.1080/09296174.2013.856132

Genette, G. (1997). Paratexts: Thresholds of Interpretation. Cambridge: Cambridge University Press.

Hart, C., \& Lukeš, D. (2009). Cognitive linguistics in critical discourse analysis: Application and

Methodological Framework for the Interdisciplinary Literary Text Analysis

Blöhmer, M. Lichtblau, A.-K. Jüttner, K. Koch, M. Krüger, R. Werning, (Eds.).

Perspektiven auf inklusive Bildung. Gemeinsam anders lehren und lernen. (pp. 261-266).

Wiesbaden: Springer. https://doi.org/10.1007/978-3-658-06955-1_39

Ito, J. P. (2013). Hypermetrical schemas, metrical orientation, and cognitive-linguistic paradigms. Journal of Music Theory, 57(1), 47-85. https://doi.org/10.1215/00222909-2017106

Jackendoff, R. (1996). Conceptual semantics and cognitive linguistics. Cognitive Linguistics, 7(1). P. 93-129. https://doi.org/10.1515/cogl.1996.7.1.93

Leezenberg, M. (2009). From cognitive linguistics to social science: Thirty years after Metaphors We Live By. Cognitive Semiotics, 5(1-2), 140-152. https://doi.org/10.1515/cogsem.2013.5.12.140

Lemberger, M. E., \& Hutchison, B. (2014). Advocating student-within-environment: A humanistic approach for therapists to animate social justice in the schools. Journal of Humanistic Psychology, 54(1). P. 28-44. https://doi.org/10.1177/0022167812469831

Livni, E. (2018). Bill Gates should embrace the power of literary fiction. Quartz. Retrieved from: https://qz.com/quartzy/1491666/bill-gates-should-embrace-the-power-of-literary-fiction/

Phoenix, C., Osborne, N. J., Redshaw, C., Moran, R., Stahl-Timmins, W., Depledge, M. H., ... \& Wheeler, B. W. (2013). Paradigmatic approaches to studying environment and human health:(Forgotten) implications for interdisciplinary research. Environmental Science \& Policy, 25, 218-228. http://doi.org/10.1016/j.envsci.2012.10.015

Rana, M. (2017). Disability in Children's Literature. Tropes, Trends and Themes. Interjuli. Internationale Kinder- und Jugendliteraturforschung. https://doi.org/10.5167/uzh-75903

Samender, A. F. (2016). The communicative-pragmatic classification of economic texts. Theory and Practice in Language Studies, 6(12), 2260-2264. http://dx.doi.org/10.17507/tpls.0612.04

Serezhnikova, R. K., Fishman, B. E., Abramenko, N. Y., Zhoglo, L. Y., \& Fishbein, M. H. (2015). Pedagogical Synergetics as the Activity Approach Basis in Professional and Pedagogical Training at the University. International Education Studies, 8(8), 148-156. http://doi.org/10.5539/ies.v8n8p148

Sirojiddinov, S., \& Normurodova, N. (2019). Pragmatics and Cognition: Intention and Conceptualization in Discourse. International Journal of Engineering and Advanced Technology, 9(1), P. 2888-2893. https://doi.org/10.35940/ijeat.A1177.109119

Úcar, X. (2013). Exploring different perspectives of Social Pedagogy: towards a complex and integrated approach. Education Policy Analysis Archives, 21(36), 1-19. https://doi.org/10.14507/epaa.v21n36.2013

UNESCO. (1994). Salamanca Declaration and Framework for Action on Special Needs Education. Retrieved from: https://unesdoc.unesco.org/ark:/48223/pf0000098427

\section{Джерело}

Драчковська, О. Зайчик-нестрибайчик та його смілива мама. Чернівці: Чорні Вівці, 2019. 32 с.

\section{References (translated and transliterated)}

Ageeva, V. (2003). Zhinochyy prostir: Feministychnyy dyskurs ukrayinskoho modernizmu. [Female Space. Feminist Discourse of the Ukrainian Modernism]. Kyiv: Fakt. 
Bakhtin, M. (2000). Epos i roman. Sbornik [Epic and Novel. Collected Writings]. S.-Petersburg: Azbuka.

Boldyrev, N. (2004). Konczeptualnoe prostranstvo kognitivnoj lingvistiki [Conceptual space of cognitive Linguistics]. Voprosy Kognitivnoi Lingvistiki, 1, 18-36.

Ermolayeva, T.V., \& Schwab, K.V. (2017). Henderni stereotypy u suchasnomu ukrayins'komu suspil'stvi. Visnyk Universytetu imeni Al'freda Nobelya. Seriya Pedahohika i

Bohdana Labinska, Iryna Osovska, Oxana Matiychuk, Nataliia Vyspinska

http://ir.duan.edu.ua/bitstream/123456789/2900/1/15.pdf

Filonenko, S. (2006). Kontseptsiya osobystosti zhinky v ukrayinskiy zhinochiy prozi 90-kh rokiv XX stolittya [The concept of a woman's personality in Ukrainian female prose of the last decade of the 20th century]. Kyiv; Nizhyn: Aspect-Polygraph Publishing House.

Golovanova, E. (2011). Osobennosti kategorizaczii i konczeptualizaczii speczialnykh znanij. Vvedenie $v$ Kognitivnoe Terminovedenie. [Characteristics of categorization and conceptualization of knowledge]. (pp. 104-139). Moscow: Nauka; Flinta.

Hundorova, T. (2002). Femina melancholica: stat i kultura v henderniy utopiyi Olhy Kobylyanskoyi [Femina melancholica: gender and culture in gender utopia of Olga Kobylianska]. Kyiv: Krytyka.

Kis, O. (2003). Modeli konstruiuvannia gendernoi identychnosty zhinky v suchasnii Ukraini. [Constructing models of gender identity in women in modern Ukraine]. Nezalezhnyi Kulturolohichnyi Chasopys " $I "$, 27, 37-58. Retrieved from: http://www.ji.lviv.ua/n27texts/kis.htm.

Kovalenko, I., Baranova, S. (2016). Animalistychna kazka yak vyd kazky. [Animal fairy tale as a separate type of tales]. Molodyi Vchenyi, 11(38), 198-201. Retrieved from: http://molodyvcheny.in.ua/files/journal/2016/11/46.pdf

Kraevskij, V. V. (2009). Nauki ob obrazovanii i nauka ob obrazovanii (metodologicheskiye problemy sovremennoy pedagogiki). Voprosy filosofii [Science education and science of education (methodological problems of modern pedagogy). Philosophy Issues], 3, 77-82. Retrieved from: http://www.kraevskyvv.narod.ru/papers/nauki.htm

Kuzava, I. (2015). Metodolohichni osnovy doslidzhennia problemy inkliuzyvnoi osvity ditei doshkilnoho viku [Methodological bases of research of the issue of inclusive education of preschool children], Pedahohichni Nauky: Teoriia, Istoriia, Innovatsiini Tekhnolohii, 6(50), 116-127. Retrieved from: http://nbuv.gov.ua/UJRN/pednauk_2015_6_18

Luzina, L. (2008). O kognitivno-diskursivnoj paradigme lingvisticheskogo znaniya [On cognitive discursive paradigm of linguistic knowledge], Paradigmy Nauchnogo Znaniya $v$ Sovremennoj Lingvistike, 40-48.

Maslova, V. (2008). Sovremennye napravleniya v lingvistike [Modern Trends in Linguistics]. Moscow: Academia.

Merezha Inkliuzyvnykh Ambasadoriv. Inclusive books. [Inclusive Ambassador Network. Inclusive books]. Retrieved from: https://inclusivebooks.org/index.php

Mogilnitskij, B. (2002). Mezhdiscziplinarnyj sintez: uroki shkoly Annalov. [Interdisciplinary synthesis: lessons of the Annales School]. Metodologicheskij sintez: proshloe, nastoyashhee, vozmozhnye perspektivy, 10-42. Retrieved from: http://klio.tsu.ru/annals.htm

Nazarova, N. (2010). Integrirovannoe (inklyuzivnoe) obrazovanie: genezis i problemy vnedreniya. [Integrated (inclusive) education: the genesis and implementation issues. Istoriya $i$ Teoriya. Soczialnaya Pedagogika, 3(9), 77-87. Retrieved from: https://cyberleninka.ru/article/n/integrirovannoe-inklyuzivnoe-obrazovanie-genezis-iproblemy-vnedreniya-1/viewer

Nesterenko, H. (2006). Synergetychnyi vymir natsii ta natsiigenezy [Synergetic dimension of nation and national genesis]. Filosofski Nauky: Scientific Journal, 40-46. 
Plakhotnik, O. (2011). Neimovirni pryhody hendernoi teorii v Ukraini [Incredible adventures of gender theory in Ukraine]. Krytyka. Retrieved from: https://krytyka.com/ua/articles/neymovirni-pryhody-gendernoyi-teoriyi-v-ukrayini

Pokhodenko, S. (2012). Heroi ukrainskykh narodnykh kazok v arkhetypovii svidomosti suspilstva [Characters of Ukrainian folk tales in the archetypal consciousness of the

Methodological Framework for the Interdisciplinary Literary Text Analysis

Poroshenko, M. (2019). Inkliuzyvna osvita [Inclusive Education]. Kyiv: Ahentstvo "Ukraïna",

Pozdniak, S. (2006). Stanovlenie i tendenczii razvitiya metodiki obucheniya geografii kak nauki $\mathrm{v}$ Rossii [Formation and trends in teaching methods development in Russian geographical science]. Doctoral dissertation. Ural State Pedagogical University.

Shaf, O. (2018). Henderne literaturoznavstvo v Ukraini: teoretyko-metodolohichni zauvahy. [Gender Literary Studies in Ukraine: theoretical and methodological notes], Naukovyi Visnyk Mizhnarodnoho Humanitarnoho Universytetu. Seriia Filolohiia, 37(1), 83-86. Retrieved from: http://www.vestnik-philology.mgu.od.ua/archive/v37/part 1/24.pdf

Shchotka, O. (2019). Henderna psykholohiia [Gender Psychology]. Nizhyn: Lysenko Publishers. Retrieved from: http://gestproject.eu/wp-content/uploads/2019/02/Gender-Psychology$\underline{\text { Shchotka.pdf }}$

Shchukin, A. (2008). Lingvodidakticheskij encziklopedicheskij slovar: bolee 2000 edinicz. [Linguo-didactic encyclopaedic dictionary: more than 2000 words]. Moscow: Astrel.

Slavova, M. (2002). Popeliushka literatury: teoretychni aspekty literatury dlia ditei [Literature Cinderella: Theoretical Aspects of Children's literature] Kyiv: Kyiv University.

Susov, I. (2007). Vvedenie v teoreticheskoe yazykoznanie [Introduction to theoretical linguistics]. Moscow: East-West.

Tsentr rozvytku dytyny "Harmoniia". (2017). Osvita dlia staloho rozvytku - novyi napriam u suchasnii osviti. [Education for Sustainable Development - A New Direction in Modern Education]. Retrieved from: http://www.garmoniya.mk.ua/articles/osvita-dlya-stalogorozvytku-novyy-napryam-u -suchasniy-osviti.html

Uliura, H. (2015). Postradyanska zhinocha proza yak sotsiokulturnyy ta estetychnyy proekt (na materiali rosiys'koyi literatury). [Post-Soviet female prose as a socio-cultural and aesthetic project (based on Russian literature)]. Kyiv: Nika-Centre.

Vovk, N., \& Zhukova, M. (2016). Zastosuvannia pedahohiky empauermentu v proektnii diialnosti uchniv na urokakh trudovoho navchannia [Application of empowerment pedagogy in project activity of pupils at lessons of labor training]. Naukovi Zapysky of Ternopil National University. Series Pedagogy, 2, 38-45. Retrieved from: http://dspace.tnpu.edu.ua/jspui/bitstream/123456789/6888/1/VOVK.pdf

Vozniuk O. (2009). Rozvytok vitchyznianoi pedahohichnoi dumky: synerhetychnyi pidkhid. [The development of national educational thought: a synergetic approach]. Zhytomyr: Zhytomyr State University. Retrieved from: http://eprints.zu.edu.ua/id/eprint/4036

Zborovska, N., Ilnytska, M. (1999). Feministychni rozdumy: na karnavali mertvykh potsilunkiv [Feminist Reflections: At the Carnival of Dead Kisses]. Lviv: Litopys.

Ziaziun, I. (2011). Tsilisnyi metodolohichnyi pidkhid u pedahohichnomu naukovomu doslidzhenni [Pedagogical research in the context of a holistic approach]. Professional Formation of Personality: Problems and Prospects: 4th International Scientific and Practical Conference. Book of abstracts. Khmelnytskyi. (7-13).

Baer, D., \& Lebowitz, Sh. (2015). 14 books that inspired Elon Musk. Business Insider, 10. Retrieved from: https://www.businessinsider.com/elon-musk-favorite-books-2015-10

Florian, L., \& Black-Hawkins, K. (2011). Exploring inclusive pedagogy. British Educational Research Journal, 37(5), P. 813-828. https://doi.org/10.1080/01411926.2010.501096 
Gaiman, N. (2013). Why our future depends on libraries, reading and daydreaming. The Guardian, 15. Retrieved from: https://www.theguardian.com/books/2013/oct/15/neilgaiman-future-libraries-reading-daydreaming

Gao, S., Zhang, H., \& Liu, H. (2014). Synergetic properties of Chinese verb valency. Journal of Quantitative Linguistics, 21(1), 1-21. https://doi.org/10.1080/09296174.2013.856132

Genette, G. (1997). Paratexts: Thresholds of Interpretation. Cambridge: Cambridge University

Bohdana Labinska, Iryna Osovska, Oxana Matiychuk, Nataliia Vyspinska

theory. Cambridge: Cambridge Scholars Publishing.

Hennies, J., \& Ritter, M. (2015). Lesen literarischer Texte in inklusiven Lerngruppen. In D. Blöhmer, M. Lichtblau, A.-K. Jüttner, K. Koch, M. Krüger, R. Werning, (Eds.). Perspektiven auf inklusive Bildung. Gemeinsam anders lehren und lernen. (pp. 261-266). Wiesbaden: Springer. https://doi.org/10.1007/978-3-658-06955-1_39

Ito, J. P. (2013). Hypermetrical schemas, metrical orientation, and cognitive-linguistic paradigms. Journal of Music Theory, 57(1), 47-85. https://doi.org/10.1215/00222909-2017106

Jackendoff, R. (1996). Conceptual semantics and cognitive linguistics. Cognitive Linguistics, 7(1). P. 93-129. https://doi.org/10.1515/cogl.1996.7.1.93

Leezenberg, M. (2009). From cognitive linguistics to social science: Thirty years after Metaphors We Live By. Cognitive Semiotics, 5(1-2), 140-152. https://doi.org/10.1515/cogsem.2013.5.12.140

Lemberger, M. E., \& Hutchison, B. (2014). Advocating student-within-environment: A humanistic approach for therapists to animate social justice in the schools. Journal of Humanistic Psychology, 54(1). P. 28-44. https://doi.org/10.1177/0022167812469831

Livni, E. (2018). Bill Gates should embrace the power of literary fiction. Quartz. Retrieved from: https://qz.com/quartzy/1491666/bill-gates-should-embrace-the-power-of-literary-fiction/

Phoenix, C., Osborne, N. J., Redshaw, C., Moran, R., Stahl-Timmins, W., Depledge, M. H., ... \& Wheeler, B. W. (2013). Paradigmatic approaches to studying environment and human health:(Forgotten) implications for interdisciplinary research. Environmental Science \& Policy, 25, 218-228. http://doi.org/10.1016/j.envsci.2012.10.015

Rana, M. (2017). Disability in Children's Literature. Tropes, Trends and Themes. Interjuli. Internationale Kinder- und Jugendliteraturforschung. https://doi.org/10.5167/uzh-75903

Samender, A. F. (2016). The communicative-pragmatic classification of economic texts. Theory and Practice in Language Studies, 6(12), 2260-2264. http://dx.doi.org/10.17507/tpls.0612.04

Serezhnikova, R. K., Fishman, B. E., Abramenko, N. Y., Zhoglo, L. Y., \& Fishbein, M. H. (2015). Pedagogical Synergetics as the Activity Approach Basis in Professional and Pedagogical Training at the University. International Education Studies, 8(8), 148-156. http://doi.org/10.5539/ies.v8n8p148

Sirojiddinov, S., \& Normurodova, N. (2019). Pragmatics and Cognition: Intention and Conceptualization in Discourse. International Journal of Engineering and Advanced Technology, 9(1), P. 2888-2893. https://doi.org/10.35940/ijeat.A1177.109119

Úcar, X. (2013). Exploring different perspectives of Social Pedagogy: towards a complex and integrated approach. Education Policy Analysis Archives, 21(36), 1-19. https://doi.org/10.14507/epaa.v21n36.2013

UNESCO. (1994). Salamanca Declaration and Framework for Action on Special Needs Education. Retrieved from: https://unesdoc.unesco.org/ark:/48223/pf0000098427

\section{Source}

Drachkovska, O. (2019). Zaichyk-nestrybaichyk ta yoho smilyva mama [Bunny Non-Hopper and His Brave Mommy]. Chernivtsi: Chorni Vivtsi. 